\title{
LEACHING OF LOW-GRADE COPPER ORES: A CASE STUDY FOR „KRAKU BUGARESKU-CEMENTACIJA” DEPOSITS (EASTERN SERBIA)
}

\author{
Grozdanka D. Bogdanović́, Velizar D. Stanković, Maja S. Trumić, \\ Dejan V. Antić, Milan Ž. Trumić
}

University of Belgrade, Technical Faculty in Bor, Vojske Jugoslavije 12, 19210 Bor, Serbia

(Received: October 5, 2016; Accepted: December 14, 2016)

\begin{abstract}
This paper deals with the investigation of column leaching of low-grade ores from the copper mine Cerovo, Serbia (the approximate $\mathrm{Cu}$ content in the ore ranges from $0.2-0.3 \%$ with $>10 \%$ copper in the form of oxide minerals). The leaching experiments were performed using sulphuric acid solutions, whereby the kinetics of copper leaching was investigated with respect to acid concentration and solid to liquid ratio. The copper concentration in the leach solution ranged from 0.80 to $1.75 \mathrm{~g} \mathrm{dm}^{-3}$. The total Cu recovery rate ranged from 30 to $56 \%$, whereas the recovery rate of copper oxide minerals ranged from 67 to $100 \%$. Furthermore, with increasing the amount of liquid phase, copper recovery increases as well, and copper oxide minerals were completely leached out. Besides copper ions, considerably high ferrous/ferric ion concentrations were achieved in the leach solution. This concentration was sufficiently high for the use of either solvent extraction or ion exchange techniques or both for further treatment of the leach solution.
\end{abstract}

Key words: low-grade ores; copper minerals; column leaching.

\section{Introduction}

The highest quantities of copper, lead and zinc in the world are obtained by sulphide ore treatment. The reserves of high-grade ores from which the extraction of non-ferrous, rare and noble metals is technologically and economically feasible are becoming scarcer year by year. At the same time, economic growth requires constantly increasing production of these metals from ores $[1,2]$. Hence, in recent years, greater attention has been paid to the processes of treatment of raw materials with low content of these metals $[3,4]$.

The increasing demand for copper in the last few years has been particularly evident not only in China but also in India, owing to the rapid industrial development in these countries. Due to the expected economic growth in other parts of the world as well (for instance South America and Africa), the demand for copper can justifiably be expected to remain high and continue to grow in the coming decades [5].

The average grade of copper ores that are currently mined in the world amounts to approximately $0.62 \%$, with annual production of $16 \mathrm{Mt} /$ year [6]. Based on the latest published results, it is estimated that mineral resources in the world contain about 1780.9 $\mathrm{Mt} \mathrm{Cu}$, with an average copper content being about $0.49 \%$ [5]. Consequently, a continuing trend of mining leads to a excavation of lower grade copper deposits, what can be expected in the future.

Increasingly, lower-grade deposits are being exploited in all larger world mines that

\#Corresponding author: gbogdanovic@tfbor.bg.ac.rs 
have been operating for over 100 years, such as Bingham Canyon (USA), El Teniente (Chile), Mt Lyell (Australia) [7, 8], as well as the Mining and Smelting Basin Bor (RTB), Serbia.

At the beginning of the 20th century, copper mines within the RTB Company ranked among the highest-grade copper mines (on average $5-6 \% \mathrm{Cu}$ in the ore). At the end of the century, the average $\mathrm{Cu}$ content in the RTB Bor mines fell to less than $0.4 \%$, which is illustrated by Fig. 1. Consequently, it is now ranked among lower-grade copper mines in the world [9].

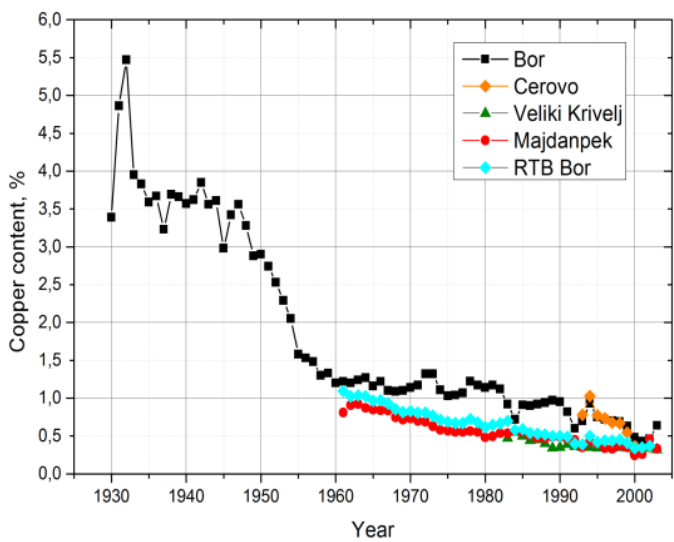

Figure 1. The changes in copper content in the ore with the time of exploitation at the RTB mines [9]

Oxide copper ore, mixed oxide-sulphide ores and low-grade copper sulphide ore, which, for economic reasons, cannot be enriched by flotation, may be processed by leaching methods. Agents for leaching copper can be acid, base, or salt solutions. Of all of these agents, sulphuric acid has been given the broadest industrial application in hydrometallurgy of copper.

The basic copper carbonate minerals, which are easily leached with the solution of sulphuric acid are: azurite, malachite and chrysocolla. Cuprite, tenorite and elemental copper, which are also found in ore deposits of copper, can be converted into a soluble form by leaching, where the chemistry of the process is simple. Copper carbonates and oxides, are present mainly in the oxidation zone - "oxide hats" above the sulphide deposits.

Sulphide copper minerals chalcocite, covellite and chalcopyrite, which are mostly present in sulphide ores of copper, can be leached only in the presence of oxidants, or with the help of bacteria from the genus Acidithiobacillus (formerly Thiobacillus), which are isolated from mine water. They were later identified as Acidithiobacillus ferrooxidans and Acidithiobacillus thiooxidans.

Kinetics of the leaching of the copper sulphide was significantly slower than the leaching of carbonates and oxides of copper, and the mechanism and the stoichiometry of the process were more complex due to the participation of oxidants in them. For the oxidation of sulphides, various oxidizing agents were used, in addition to oxygen from the air and ferric - ion was most widely used on an industrial scale. Ferric ion mostly occurs in the landfill itself in the form of $\mathrm{Fe}_{2}\left(\mathrm{SO}_{4}\right)_{3}$ as the result of decomposition of pyrite. Therefore, pyrite, which is always present in the ore deposits of copper, is an important mineral, as its oxidation supplies leaching solution with ferric sulphate and partly sulphuric acid $[10,11]$.

Mine development and exploitation of sulphide mineral deposits, as is the case at RTB Bor, imply the formation of waste dumps of the so called out-of-balance raw materials in the vicinity of the mine. Over time, atmospheric oxygen and bacteria cause oxidation of pyrite and other sulphide minerals. As a result of weathering, the products of oxidation are dissolved and leached in the form of acid mine drainages (AMDs), whose influence on the environment is extremely harmful due to a high content of heavy metal ions and sulphuric acid [12-15]. 
Oxidation reactions and leaching of copper minerals and pyrite from low-grade copper ores and mining waste (waste rock, overburden, oxidized portions of the ore body) proceed according to the following stoichiometric equations shown in Table 1 [16].

Dump, heap and in-situ leaching are the most common hydrometallurgical methods for copper recovery from these raw materials on an industrial scale [16-18]. A considerable amount of copper is recovered using these methods, which reduces uncontrollable pollution of the environment with heavy metal ions and acid occurring as a result of the natural leaching processes represented by the equations in Table 1. Currently, leaching in combination with the solvent extraction and electrolysis account for $20 \%$ of the total amount of copper produced in the world $[19,20]$. These methods are most widely used in the USA and Chile.

Table 1. Reactions for leaching copper minerals and pyrite

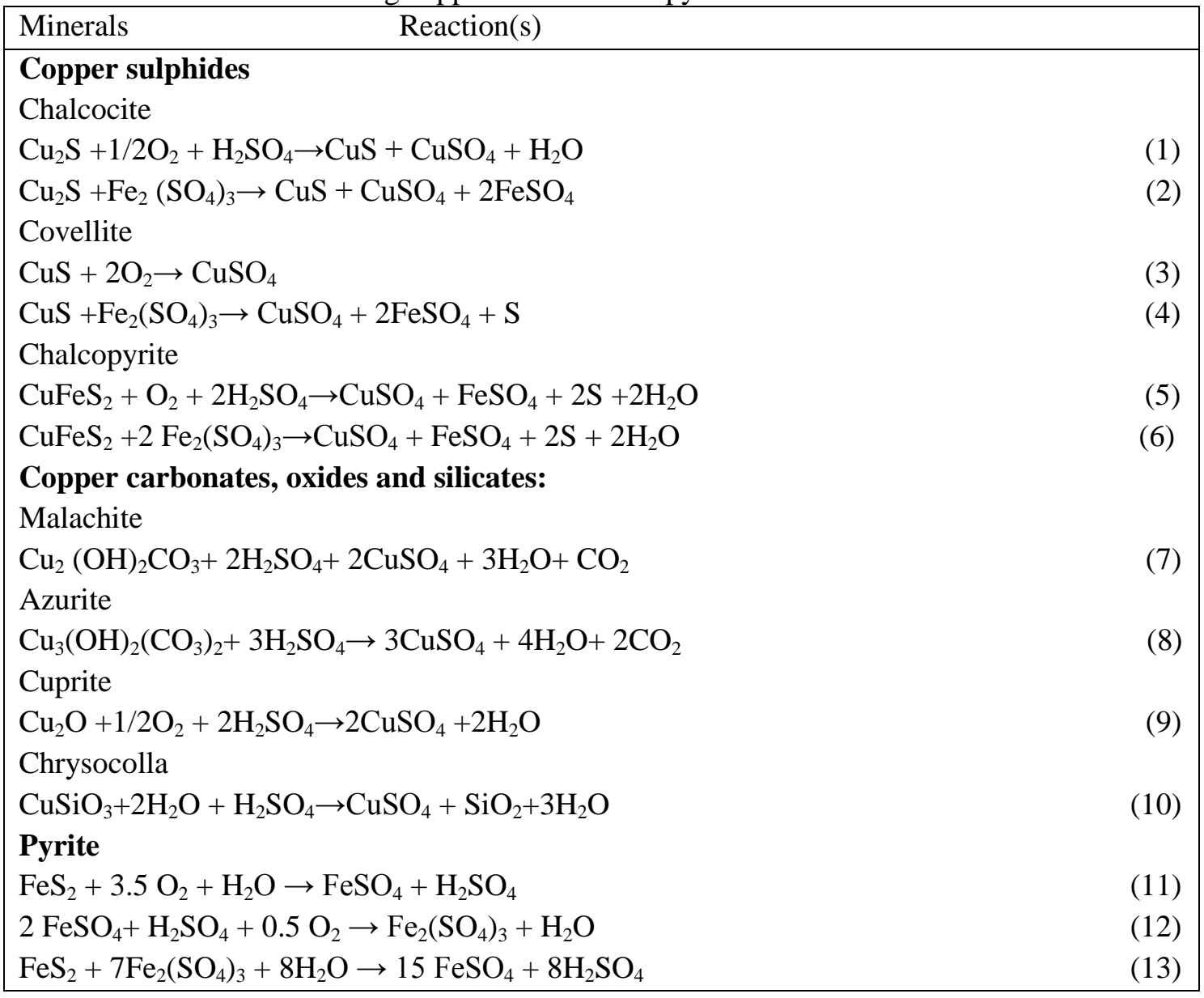

The potential raw material for obtaining copper within the RTB Bor include oxide and mixed oxide-sulphide ores at the copper deposit "Kraku Bugaresku-Cementacija".
This deposit, in the calculation of reserves in the contour of boundary contents of $0.2 \%$ $\mathrm{Cu}$, is consisted of four ore bodies $(\mathrm{C} 1, \mathrm{C} 2$, $\mathrm{C} 3$ and $\mathrm{C} 4$ ), which are similar in generic 
origin, but with some differences in the composition of the copper mineralization. From the surface toward the depth, there is a vertical zoning, where we can recognise: the oxidation zone, the zone of secondary sulphide enrichment or, so called cementation zone, transient and primary zone, as is illustrated in Table $2[21,22]$.

Table 2. Copper content in the ore bodies "Kraku Bugaresku - Cementacija"

\begin{tabular}{|l|c|c|c|c|c|c|}
\hline \multirow{2}{*}{ ORE SAMPLE } & \multicolumn{2}{|c|}{ TOTAL COPPER } & \multicolumn{2}{c|}{ OXIDE COPPER } & \multicolumn{2}{c|}{ SULPHIDE COPPER } \\
\cline { 2 - 7 } & Conc. \% & Fraction \% & Conc. \% & Fraction \% & Conc. \% & Fraction \% \\
\hline Cementation zone C2 & 0.32 & 100 & 0.13 & 40.62 & 0.19 & 59.38 \\
\hline Transient zone C2 & 0.23 & 100 & 0.04 & 17.39 & 0.19 & 82.61 \\
\hline Cementation zone C3 & 0.31 & 100 & 0.07 & 22.26 & 0.24 & 77.73 \\
\hline Transient zone C3 & 0.33 & 100 & 0.024 & 7.27 & 0.31 & 92.73 \\
\hline C4 Average [1] & 0.27 & 100 & 0.03 & 11.20 & 0.24 & 88.80 \\
\hline${ }^{*}$ Sample from C1 & 0.18 & 100 & 0.08 & 44.40 & 0.102 & 55.60 \\
\hline
\end{tabular}

* Sample taken from an edge at the open pit Cerovo reach with oxide copper minerals

Low average copper content and increased participation of oxide copper minerals in these ore bodies, leads to serious technological problems in mineral processing plant, namely to reduction of copper in the flotation concentration (about $60 \%$ on average). This leads to large copper losses. Therefore, studies were conducted to obtain copper from these raw materials with the process of leaching of the present minerals and subsequent extraction of copper from the leach solution.

This paper describes the influence of acid concentration and influence of solid/liquid ratio on copper leaching rate from the ore bodies Cerovo-Cementacija 2 (C2).

\section{Experimental}

\subsection{Material}

The leaching experiments were conducted using two representative ore samples taken from the Cerovo-Cementacija 2 ore body with various copper oxide content. The samples originate from the drilling cores taken from different depths of the cementation and transient zones. Subsequent to drying, homogenization and reduction of samples they were characterized based on particle size analysis, chemical and mineralogical composition.

The particle size distribution is shown in Fig. 2.

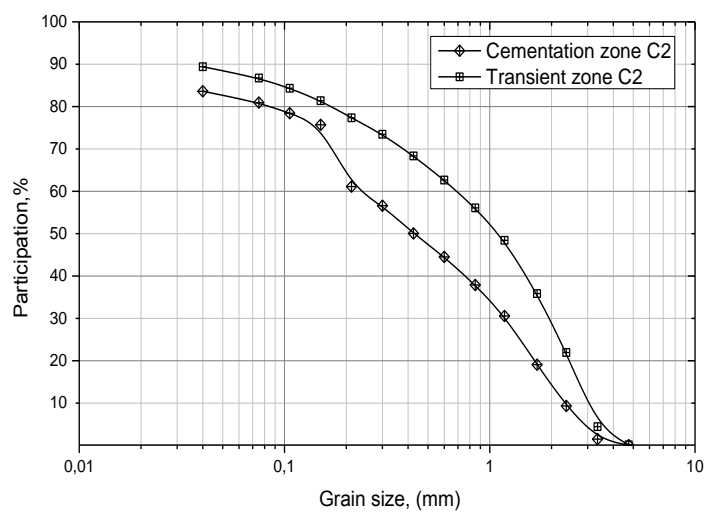

Figure 2. Grain size distribution of the ore sample

The results of chemical analysis of the samples are shown in Table 3.

It can be concluded that the analysed samples represent a low-grade copper ore with a high content of non-sulphide minerals. As indicated by these data, the percentage of copper oxide compared to the total amount of copper ranged from $40.6 \%$ (cementation zone) to $17.3 \%$ (transient zone). 
Table 3. Chemical analysis of the ore samples

\begin{tabular}{|l|c|c|c|c|c|c|c|c|c|c|c|c|}
\hline Component & $\begin{array}{c}\mathrm{Cu}- \\
\text { total }\end{array}$ & $\begin{array}{c}\mathrm{Cu}- \\
\text { oxide }\end{array}$ & $\begin{array}{c}\mathrm{Cu}- \\
\text { sulfide }\end{array}$ & $\mathrm{S}$ & $\mathrm{SiO}_{2}$ & $\mathrm{Fe}$ & $\mathrm{Al}_{2} \mathrm{O}_{3}$ & $\mathrm{CaO}$ & $\mathrm{MgO}$ & $\mathrm{Ni}$ & $\mathrm{Zn}$ & $\mathrm{Mn}$ \\
\hline $\begin{array}{l}\text { Cementation } \\
\text { zone C2,\% }\end{array}$ & 0.32 & 0.13 & 0.19 & 2.66 & 63.14 & 3.37 & 19.42 & 0.47 & 2.11 & $<0.007$ & 0.016 & 0.012 \\
\hline $\begin{array}{l}\text { Transient } \\
\text { zone C2,\% }\end{array}$ & 0.23 & 0.04 & 0.19 & 1.95 & 60.64 & 4.14 & 18.47 & 0.66 & $2 ., 84$ & $<0.007$ & 0.010 & 0.012 \\
\hline
\end{tabular}

Mineralogical analysis and X-ray diffraction revealed that the most abundant sulphide mineral was pyrite, and of copper minerals, the most abundant were chalcocite and chalcopyrite. Copper is mostly present in the form of cuprite, malachite and azurite. The results of qualitative mineralogical analyses indicated the presence of other iron minerals apart from pyrite such as: magnetite, goethite, rutile, limonite as well as smaller amounts sphalerite, molybdenite and galenite in quartzsulphide wires. Among the gangue minerals the most abundant is quartz.

\subsection{Column leaching experiments}

Leaching experiments were carried out in PVC columns, $110 \mathrm{~mm}$ in diameter and 1000 $\mathrm{mm}$ in height. At the bottom of each column there was a perforated plate serving as a bed carrier over which filter paper was placed to prevent small solid-phase fractions from passing through. Eight kilograms of ore, grain size range $-5+0 \mathrm{~mm}$, was put into each column. Over the ore, a bed of silica sand was placed $1 \mathrm{~cm}$ in height in order for sulphuric acid solution to be more evenly distributed over the whole cross section of the column. The leaching agent used in the experiment was a $0.01 \mathrm{M}$ and $0.1 \mathrm{M}$ sulphuric acid solution. Above each column, there was a reservoir with sulphuric acid solution $(\mathrm{V}=10$ $\mathrm{dm}^{3}$ ) which gravitationally flows out into the column. Under the columns, reservoirs were placed for the collection of the pregnant leach solution. At definite intervals, the samples of leach solution were taken for analysis and $\mathrm{pH}$ measurements. After $\mathrm{pH}$ adjustment to the initial value, the solutions were re-circulated through the column. The $\mathrm{pH}$ value adjustment was performed using a sulphuric acid solution of a known concentration. A layer of the leaching agent was kept constant to ensure a constant flow. The flow was controlled by taps at the bottom of each column and was kept constant throughout the experiment. The flow rate was about $12 \mathrm{~cm}^{3} / \mathrm{min}$ and the leaching experiments lasted 30 days.

Copper and iron concentration in the leach solutions was determined using a UV/VIS spectrophotometer Rayleigh UV 9200 and atomic absorption spectroscopy (AAS). The $\mathrm{pH}$ values of the solutions were periodically changed using the JENCO $6250 \mathrm{pH}$ meter.

\section{Results and discussion}

\subsection{Influence of sulphuric acid concentration}

The influence of sulphuric acid concentration on the leaching of copper and iron was investigated by leaching ore samples, at a solid to liquid ratio of $1: 1$, class of size $(-5+$ 0) $\mathrm{mm}$. The initial $\mathrm{H}_{2} \mathrm{SO}_{4}$ concentrations in the leach solution were $0.01 \mathrm{M}$ and $0.1 \mathrm{M}$ and were kept at that level by periodic addition of sulphuric acid. The obtained results of the leaching are presented in Fig. 3.

Curves in Fig. 3a show an increase the copper and iron ions with time. During the leaching process of the ore from the cementation zone after a period of 28 days, the concentration of copper in the leach solution was $1.75 \mathrm{~g} \mathrm{dm}^{-3}$. 


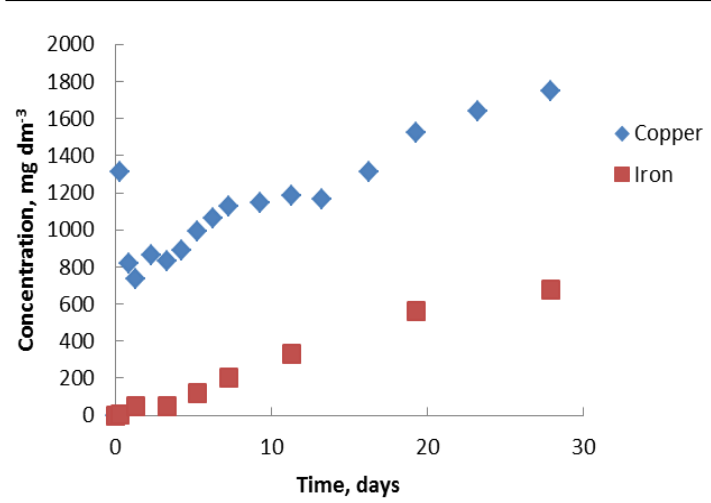

a)

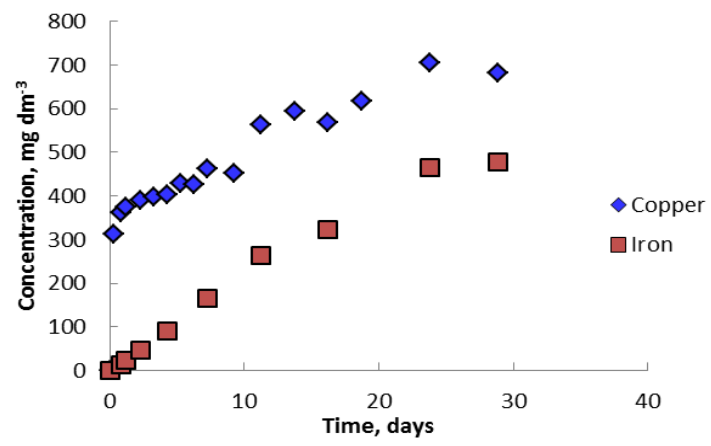

b)

Figure 3. Change of concentration copper and iron ions concentrations with time during copper ore leaching with $0.01 \mathrm{M} \mathrm{H}_{2} \mathrm{SO}_{4}$; Particles size: $-5+0 \mathrm{~mm}$ :

a) cementation zone, b) transient zone

The concentration of iron ions in the leach solution was significantly lower than the concentration of copper ions, with the amount of $0.67 \mathrm{~g} \mathrm{dm}^{-3}$.

Figure $3 \mathrm{~b}$ shows similar behaviour like during the leaching process of the ore from cementation zone of the ore body. Obtained kinetic curves of the leaching confirm that, but the copper concentration in the solution was half in the case of the transition zone $\left(\sim 0.80 \mathrm{~g} \mathrm{dm}^{-3} \mathrm{Cu}\right)$, which is due to mineralogical composition of the ore (lower copper content in the form of oxide minerals). The concentration of iron in the solution was about $0.5 \mathrm{~g} \mathrm{dm}^{-3}$.
Concurrently with leaching of oxide minerals, there was a process of oxidation of sulphide copper minerals thanks to the $\mathrm{Fe}^{3+}$ ions, which are present as the result of the leaching of iron oxides. In extended leaching experiments, molecular oxygen dissolved in the leach solution can have the role of an oxidant, oxidizing $\mathrm{Fe}^{2+}$ to $\mathrm{Fe}^{3+}$. The generated ferric ion will act as an oxidant for the subsequent oxidation of sulphide copper minerals.

Under natural conditions, the presence of certain indigenous species of bacteria has a favourable effect on these processes, oxidizing $\mathrm{Fe}^{2+}$ to $\mathrm{Fe}^{3+}$, which can affect the rate of leaching of copper sulphide minerals. This practically means that the leaching of copper in the dump, or heap takes a very long time - even years, depending on the size of the dump, or heap, copper content in it and access to agents for leaching copper minerals $[4,16]$.

Figure 4 shows the influence of the concentration of acids on the recovery of copper.

During the leaching of the ore with sulphuric acid concentration of 0.1 and 0.01 $\mathrm{M} \mathrm{H}_{2} \mathrm{SO}_{4}$, leaching degree of total copper ranged from about 27 to about $55 \%$, respectively. Given that the degree of leaching of total copper was larger than the amount of oxide copper present in the sample (41\%), it can be concluded that an oxidation reaction occurs between copper sulphide minerals, followed by dissolution of so formed oxides.

The copper content in the leach solution has reached, after 5 days about $1 \mathrm{~g} \mathrm{dm}^{-3}$ (Fig. $3 a$ ). At the very beginning of the process (first two days), around $67 \%$ of copper oxide was leached, after and after 10 days of leaching, leaching degree was over $90 \%$.

Figures 3 and 4 show that the leaching process of copper minerals takes place with very different rates. Significant high rate was achieved of the process during the first 2-5 days, to be reduced 1-2 order of magnitude, 
depending on the conditions of the process. During the testing of the sample leached with the solution $0.01 \mathrm{M} \mathrm{H}_{2} \mathrm{SO}_{4}$ any significant acid consumption was not observed.

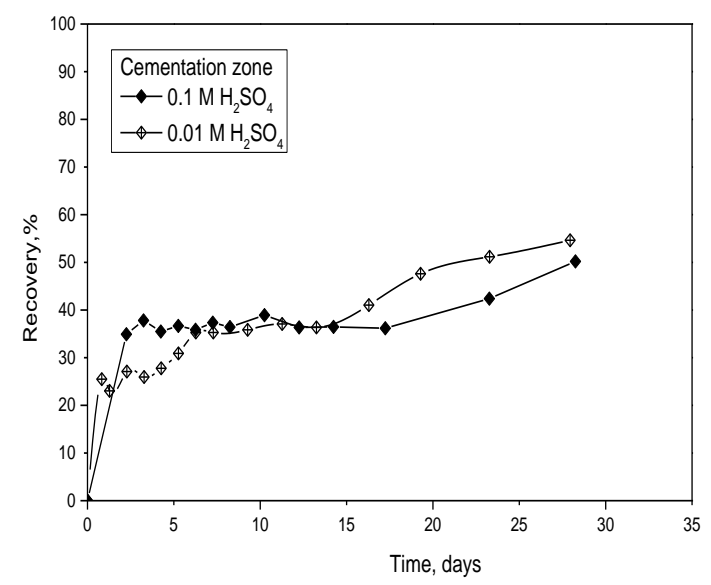

a)

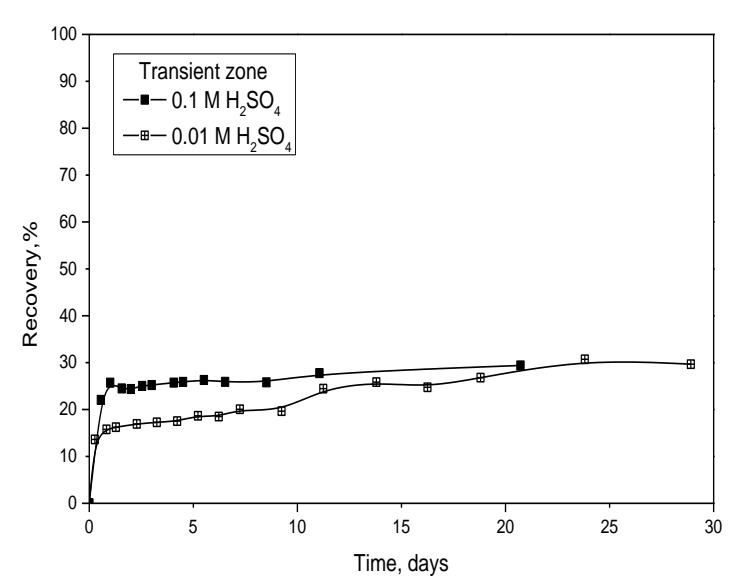

b)

Figure 4. Effect of sulphuric acid concentration on copper recovery $(\mathrm{S}: \mathrm{L}=1: 1)$ :

a) cementation zone, b) transient zone.

\section{2. pH behaviour during column leaching}

The change in the $\mathrm{pH}$ value of the pregnant leach solution with time is shown in Fig. 5a and $5 b$.

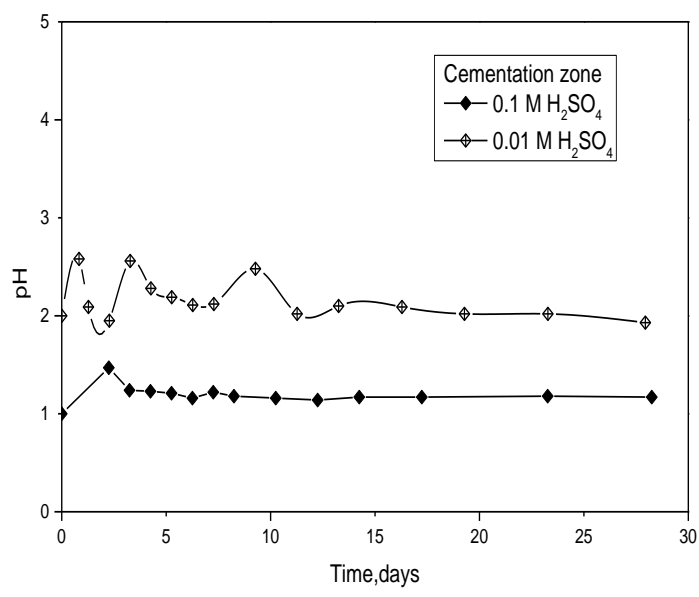

a)

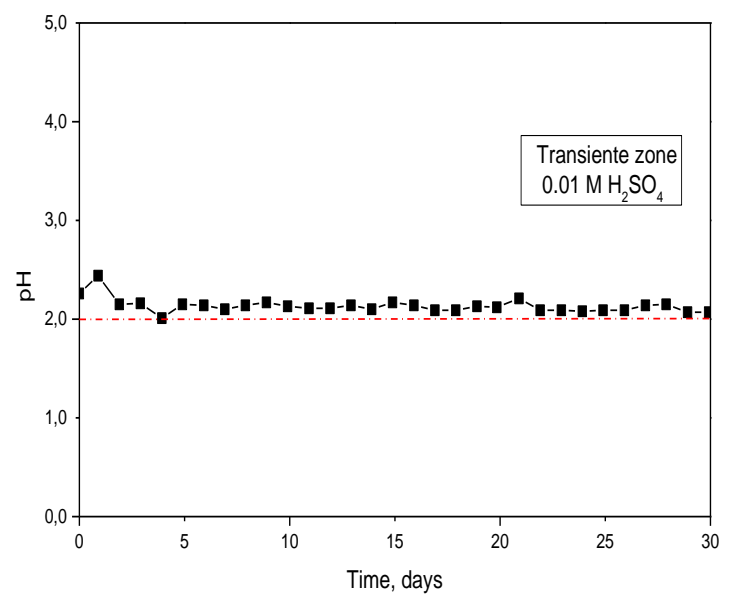

b)

Figure 5. Change in the $\mathrm{pH}$ value of the leaching solution vs. time:

a) cementation zone, b) transient zone.

It can be observed that the $\mathrm{pH}$ value increases in the initial period of the leaching process (up to two days), after which it slightly decreases with time. During the leaching process, sulphuric acid is consumed due to wanted reactions with copper minerals, but also due to unwanted reactions with oxides and carbonates of alkaline earth 
metals, which is manifested by an increase in the $\mathrm{pH}$ value of the leach solution by almost one unit, that is, the decrease in $\mathrm{H}^{+}$ concentration in the leach solution.

In order to provide sulphuric acid throughout the process and maintain constant acidity of the leach solution, the $\mathrm{pH}$ was adjusted to 2.0 by adding sulphuric acid with each recirculation of the leach solution. The greatest amount of acid is consumed in leaching copper oxides (Eqs. (7)-(10). A considerable amount is of sulphuric acid is consumed in leaching other oxide and carbonate minerals present in the ore, whereas a slight amount is consumed in leaching secondary copper sulphide minerals (Eqs. (1)(6)). However, a part of acid is generated during the reaction of pyrite leaching (Eqs. (11) and (13)), which is indicated by the amount of iron ions in the final leach solution.

Pyrite oxidation is carried out in several stages, including the oxidation of pyrite, iron (III) hydrolysis and formation and precipitation of secondary products. These products consist of iron (III) oxide / oxyhydroxides (i.e. geothite- $\mathrm{FeO}(\mathrm{OH})$ or $\alpha$-FeOOH; ferrihydrite $\quad \mathrm{Fe}_{5} \mathrm{HO}_{8} \cdot 4 \mathrm{H}_{2} \mathrm{O}$ or $\mathrm{Fe}_{2} \mathrm{O}_{3} \cdot 9 \mathrm{H}_{2} \mathrm{O}$ ) and iron (III) sulphate (i.e. schwertmannite $\mathrm{Fe}_{8} \mathrm{O}_{8}(\mathrm{OH})_{6} \mathrm{SO}_{4}$ and $\left.\mathrm{Fe}_{16} \mathrm{O}_{16}(\mathrm{OH})_{10}\left(\mathrm{SO}_{4}\right)_{3}\right)$ as well as from much more stable jarosite $\mathrm{KFe}_{3}\left(\mathrm{SO}_{4}\right)_{2}(\mathrm{OH})_{6}$. The hydrolysis and precipitation of iron hydroxide (reaction 14) and to a lesser extent of jarosite (reaction 15), will produce the most of acid during the oxidation of pyrite [23].

$$
\begin{aligned}
& \mathrm{Fe}^{3+}+3 \mathrm{H}_{2} \mathrm{O} \leftrightarrow \mathrm{Fe}(\mathrm{OH})_{3}+3 \mathrm{H}^{+} \\
& \mathrm{Fe}^{3+}+2 \mathrm{H}_{2} \mathrm{O} \leftrightarrow \mathrm{FeOOH}_{(\mathrm{s})}+3 \mathrm{H}^{+}
\end{aligned}
$$

\subsection{Effect of solid to liquid ratio}

The effect of solid/liquid ratio (S:L) was investigated by leaching the ore samples with a $0.01 \mathrm{M} \mathrm{H}_{2} \mathrm{SO}_{4}$ solution at a solid to liquid ratio of $1: 1$ and $1: 2$. The obtained results are shown in Fig. 6 and Fig. 7.

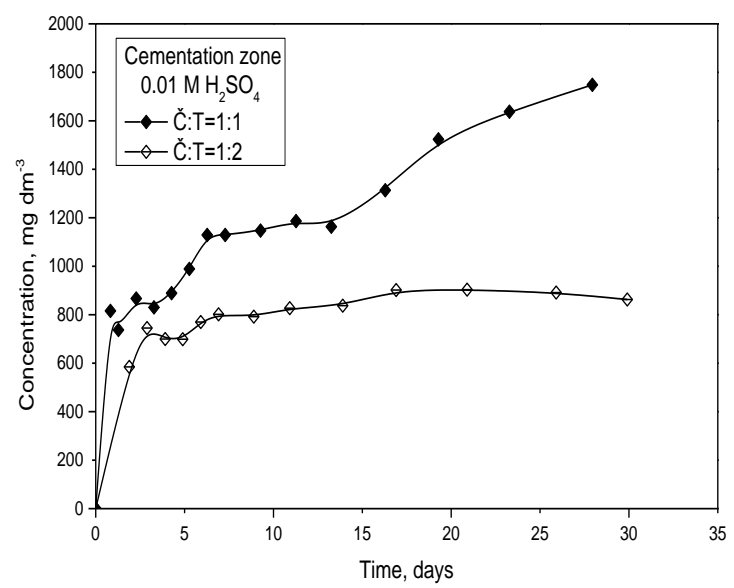

a)

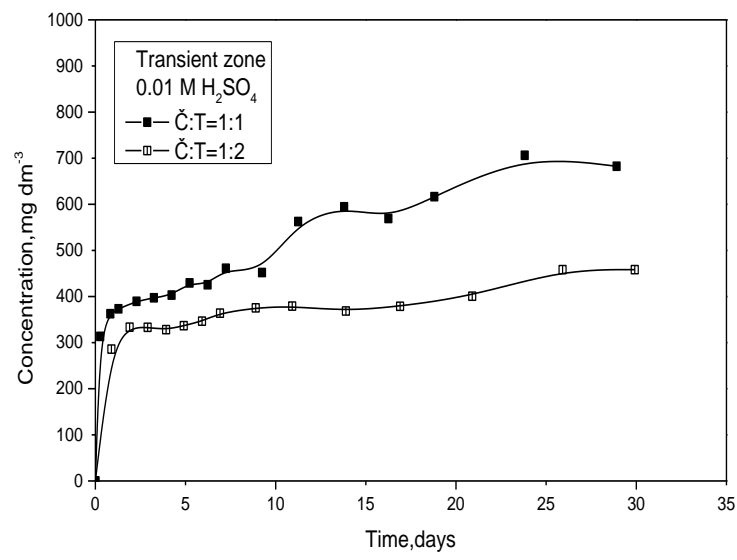

b)

Figure 6. Copper concentration in the leach solution vs. time at various solid to liquid ratios: a) cementation zone, b) transient zone.

Fig. 6 and Fig. 7 show that, except for the first two days, when there was a sudden jump in the concentration of copper ions in the leach solution, the process takes place at almost a constant rate in case of $\mathrm{S}: \mathrm{L}=1: 1$, while the copper concentration remains almost constant for $S: L=1: 2$ and for the leaching process time. 


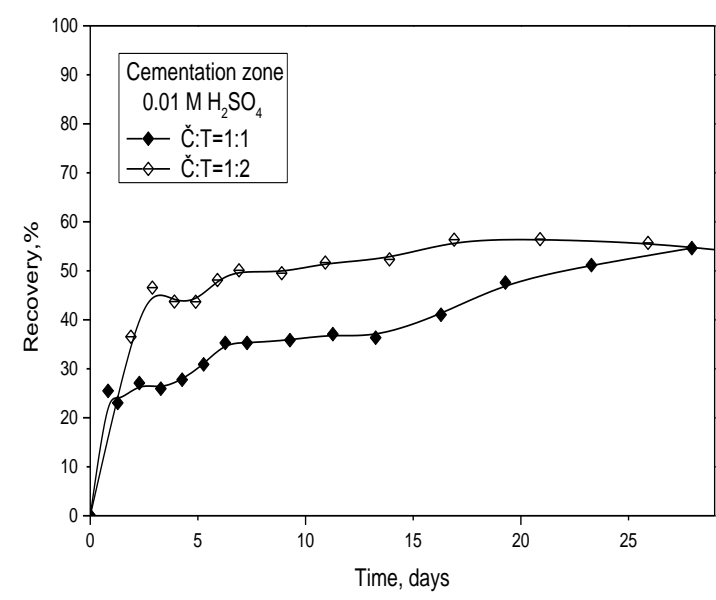

a)

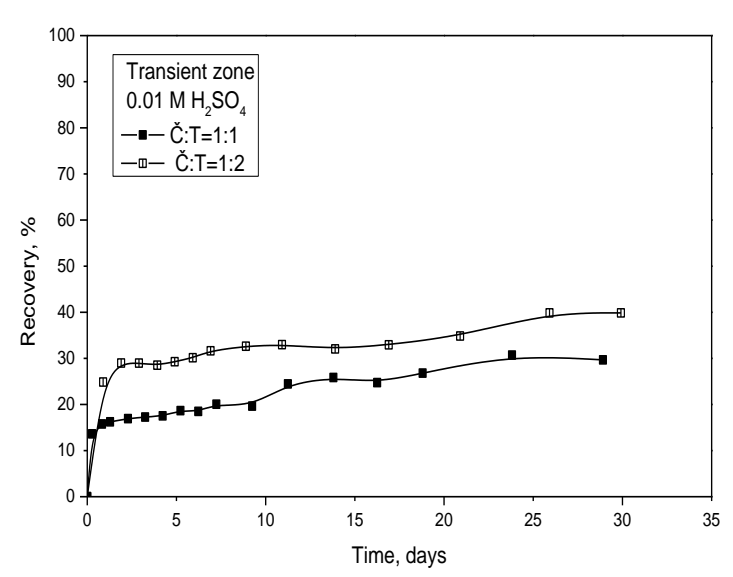

b)

Figure 7. Effect of solid to liquid ratio on copper and iron recovery rates in leaching with $0.01 \mathrm{M} \mathrm{H}_{2} \mathrm{SO}_{4}$ : a) cementation zone, b) transient zone.

With the increasing proportion of the liquid phase, i.e. leaching agent in the suspension, there was an increase in the degree of leaching of total amount of copper, but also a decrease of the concentration of copper in leach solutions. During the leaching with a solution concentration of $0.01 \mathrm{M}$ $\mathrm{H}_{2} \mathrm{SO}_{4}(\mathrm{~S}: \mathrm{L}=1: 2)$, after 7 days about $50 \%$ of the total copper was leached.
The concentration of copper in the leach solution was about $0.8 \mathrm{~g} \mathrm{dm}^{-3}$ and kept this value through the whole process. After 30 days of leaching a concentration of copper in the solution was about $0.9 \mathrm{~g} \mathrm{dm}^{-3}$, which was two times lesser compared to the leach solution at a ratio $\mathrm{S}: \mathrm{L}=1: 1$. Total copper leaching degree, after 30 days of leaching was about $56 \%$. Changing ratio S:L did not significantly affect the leaching of oxide copper, because in both cases, almost all the copper oxide was converted into ion form, which can be determined on the basis of its participation in the raw material.

Fig. 6b, has a similar shape regardless of the experimental conditions, that is, leaching of the ore from the transition zone occurs in two stages, as in the previous case.

During the leaching with $0.01 \mathrm{M} \mathrm{H}_{2} \mathrm{SO}_{4}$ $(\mathrm{S}: \mathrm{L}=1: 2)$ for a period of 2 days, leaching solution concentration of about $0.3 \mathrm{~g} \mathrm{dm}^{-3}$ was obtained, where about $30 \%$ of the total copper was leached. After 30 days of leaching, copper concentration in the solution was about $0.46 \mathrm{~g} \mathrm{dm}^{-3}$, where a degree of leaching of total copper was about $40 \%$, as seen in Fig. $6 \mathrm{~b}$ and Fig.7b. During the leaching of the ore at ratio $S: L=1: 1$, the concentration of copper in solution was almost twice as high, so that after 29 days of leaching copper concentration was $0.68 \mathrm{~g}$ $\mathrm{dm}^{-3}$, where a degree of leaching of total copper was about $30 \%$.

These results are in agreement with the kinetics of acid leaching of low-grade sulphide-oxide ores under atmospheric conditions. It has been found that the copper recovery rate in heap leaching of sulphide minerals usually increases rapidly in the initial stage of the leaching process, with $50-60 \%$ of the metal being leached out in the first few months. Subsequently, the leaching process slows down and proceeds at a constant dissolution rate, during which $80-90 \%$ of the metal is leached out in the next 12 to 24 
months [4]. In leaching copper oxide minerals or mixed sulphide-oxide ores, more than $90 \%$ of copper is commonly leached out in the first 30 days.

In heap leaching of primary copper sulphides, the achieved recovery rates are $60-70 \%$ in $1-2$ years, subsequent to which leaching stops as not being technologically and economically feasible due to slow leaching rates [24].

\section{Conclusions}

Based on the obtained it can be concluded that it is a low-grade copper ore with a high content of non-sulphide minerals (copper oxide content $>15 \%$ ). It can be noted that there is more iron in the transition zone compared to the cementation zone.

Based on the shape of curves concentration - time, the leaching takes place in two stages. In the first stage, which lasts 2 to 5 days, the concentration of copper ions in the leach solution was going rapidly with time up. After the first stage, leaching process rate decreases significantly for the rest time of leaching. High rate of the leaching process in the first period was the result of easily available oxide copper.

Due to the recirculation of leach solution, the copper concentration in the final solution, after ending the experiment (time interval about one month), was in a range from 0.8 to $1.8 \mathrm{~g} \mathrm{dm}^{-3}$. The concentration of iron ions was in the range values - from 0.5 to $0.7 \mathrm{~g} \mathrm{dm}^{-3}$.

Based on the collected results it can be noted that, after a certain time of leaching, leach solutions with significant concentrations of copper (about $1 \mathrm{~g} \mathrm{dm}^{-3}$ ) are obtained, which could be further treated with SX-EW process, or a similar procedure.

The total $\mathrm{Cu}$ recovery rate during the leaching period of about 30 days ranged from 30 to $56 \%$, implying that, in addition to complete leaching of copper oxide, it leads to the oxidation of sulphide minerals, either due to the presence of ferric ions and oxygen dissolved in the solution.

\section{Acknowledgments}

This research is supported by the Ministry of Education, Science and Technological Development, Government of the Republic of Serbia within the framework of the Projects OI 172031 and TR 33 007. The authors are gratefully acknowledged.

A part of this study was presented at the $48^{\text {th }}$ International October Conference on Mining and Metallurgy, University of Belgrade, Technical faculty in Bor, Bor, on $28^{\text {th }}$ September to $01^{\text {st }}$ October 2016.

\section{References}

[1] Anjum, F., Shahid, M., Akcil, A. (2012) Biohydrometallurgy techniques of low grade ores: A review on black shale. Hydrometallurgy 117-118, 1-12.

[2] Zhang, L., Yang, J., Cai, Z., Zengwei Yuan, Z. (2014) Analysis of copper flows in China from 1975 to 2010. Science of the Total Environment 478, 80-89.

[3] Wu, A., Yin, S., Yang, B., Wang, J., Qiu, G. (2007) Study on preferential flow in dump leaching of low-grade ores. Hydrometallurgy 87, 124-132

[4] Ghorbani, Y., Becker, M., Mainza, A., Franzidis, J-P., Petersen, J. (2011) Large particle effects in chemical/biochemical heap leach processes - A review. Minerals Engineering 24, 1172-1184.

[5] Northeya, S., Mohrb, S., Mudda, G.M., Wenga, Z., Giurcob, D. (2014) Modelling future copper ore grade decline based on a detailed assessment of copper resources and mining. Resources, 
Conservation and Recycling 83, 190201.

[6] Mason, L., Mikhailovich, N., Mudd, G., Sharpe, S., Giurco, D. (2013) Advantage Australia: resource governance and innovation for the Asian century, prepared for CSIRO Minerals Down Under Flagship by the Institute for Sustainable Futures (UTS, Sydney, Australia) and Monash University, Melbourne. ISBN 978-1-922173-49-2 (online).

[7] Crowson, P. (2012) Some observations on copper yields and ore grades. Resources Policy 37, 59-72.

[8] Mudd, G.M. (2010) The Environmental sustainability of mining in Australia: key mega-trends and looming constraints. Resources Policy 35, 98-115.

[9] Mitrović, Z., Jovanović, R. (2007) Sto godina Borskog rudarstva 1903-2003. Sedamdeset pet godina basenskih flotacija 1929-2003. Rudarskotopioničarski basen Bor, Megatrend univerzitet Beograd, (In Serbian).

[10] Lowson, R.T, Aqueous Oxidation of Pyrite by Molecular Oxygen (1982) Chemical Rewiews 82, 461-497.

[11] Chandra, A.P., Gerson A.R. (2010) Review. The mechanisms of pyrite oxidation and leaching: A fundamental perspective, Surface Science Reports 65,293-315.

[12] Egiebor, N.O and Oni, B. (2007) Acid rock drainage formation and treatment: a review. Asia-Pacific Journal of Chemical Engineering 2, 47-62.

[13] Bogdanović, G. D., Trumić, M. Ž., Stanković, V., Antić, D.V., Trumić, M. S. and Milanović, Z. (2013) Mine Waters From Mining \& Smelting Basin Bor - A Resource For The Recovery of Copper or Polluter of The Environment, Recycling and Sustainable Development 6, 41-50, (In Serbian).
[14] Brough, C.P., Warrender, R., Bowell, R.J., Barnes, A., Parbhakar-Fox, A. (2013) The process mineralogy of mine wastes, Minerals Engineering 52, 125135.

[15] Bode, A., Yoga, P., Xhulaj, D., Xhulaj, S. (2010) Mining residues around lake Ohrid, Journal of Mining and Metallurgy, 46A(1), 1-31.

[16] Watling, H.R. (2006) The bioleaching of sulphide minerals with emphasis on copper sulphides - A review, Hydrometallurgy 84, 81 -108.

[17] Shayestehfar, M.R., Nasab, S.K., Mohammadalizadeh, H. (2008) Mineralogy, petrology, and chemistry studies to evaluate oxide copper ores for heap leaching in Sarcheshmeh copper mine, Kerman, Iran, Journal of Hazardous Materials 154, 602-612.

[18] Dudeney, A.W.L., Chan, B.K.C., Bouzalakos, S. and Huisman, J.L. (2013) Management of waste and wastewater from mineral industry processes, especially leaching of sulphide resources: state of the art, International Journal of Mining, Reclamation and Environment 27(1) 2-37.

[19] Watling, H.R. (2013) Chalcopyrite hydrometallurgy at atmospheric pressure: 1. Review of acidic sulfate, sulfatechloride and sulfate-nitrate process options, Hydrometallurgy 140, 163-180.

[20] Norgate, T., Jahanshahi, S. (2010) Low grade ores - Smelt, leach or concentrate? Minerals Engineering 23, 65-73.

[21] Stanković,V., Bogdanović,G., Antić, D., Miličević, D. (2015) Out-of-balance copper ores leaching- A case study for the ore deposit Kraku Bugaresku, 47th International October Conference on Mining and Metallurgy, Bor, 04-06 October 2015, Bor Lake, Bor, Serbia, 141-144. 
[22] Bogdanović,G., Stanković,V., Antić, D., Trumić, M., Miličević, D., Trumić, M. (2016) Acid leaching of low-grade copper ores, $48^{\text {th }}$ International October Conference on Mining and Metallyrgy, $28^{\text {th }}$ September to $01^{\text {st }}$ October 2016, Bor, Serbia, 483-487.
[23] Dimitrijević, M.D. (2012) Acid mine drainage. Copper 37 (1), 33-44.

[24] Dreisinger, D. (2006) Copper leaching from primary sulfides: Options for biological and chemical extraction of copper, Hydrometallurgy 83, $10-20$. 


\title{
LUŽENJE RUDA BAKRA SA NISKIM SADRŽAJEM: STUDIJA SLUČAJA ZA LEŽIŠTE „KRAKU BUGARESKU-CEMENTACIJA” (ISTOČNA SRBIJA)
}

\author{
Grozdanka D. Bogdanović\#, Velizar D. Stanković, Maja S. Trumić, \\ Dejan V. Antić, Milan Ž. Trumić
}

Univerzitet u Beogradu, Tehnički fakultet u Boru, Vojske Jugoslavije 12, 19210 Bor, Srbija

(Primljen: 5. Oktobar, 2016.; Prihvaćen: 14. Decembar, 2016.)

\begin{abstract}
Izvod
Ovaj rad se bavi istraživanjem luženja u koloni ruda sa niskim sadržajem bakra iz rudnika Cerovo, Srbija (približni sadržaj Cu u rudi varira u opsegu $0.2-0.3 \%$ sa >10\% bakra u formi oksidnih minerala). Eksperimenti luženja izvedeni su primenom rastvora sumporne kiseline, pri čemu je konetika luženja ispitivana uzimajući u obzir koncentraciju kiseline i odnos čvrste prema tečnoj fazi. Koncentracija bakra u lužnom rastvoru varirala je od 0.80 do $1.75 \mathrm{~g} \mathrm{dm}^{-3}$. Ukupno iskorišćenje Cu variralo je od 30 do $56 \%$ pri čemu je iskorišćenje oksidnih minerala bakra bilo u rasponu od 67 do $100 \%$. Dodatno, sa povećanjem količine tečne faze raste iskorišćenje bakra, a oksidni minerali bakra su u potpunosti izluženi. Pored jona bakra postignute su i značajne koncentracije feritnih jona u lužnom rastvoru. Ove koncentracije su bile dovoljno visoke za primenu solventne ekstrakcije ili tehnika jonske izmene ili oboje za dalji tretman lužnog rastvora.
\end{abstract}

Ključne reči: siromašne rude; minerali bakra; luženje u koloni.

\footnotetext{
${ }^{\#}$ Kontakt adresa autora: gbogdanovic@tfbor.bg.ac.rs
} 